\title{
Crescendo na formação através da redação de artigos científicos
}

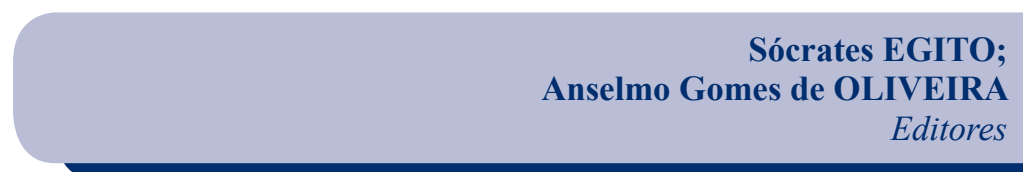

A crescente demanda na produção de artigos científicos tem revelado como grande descoberta, a possibilidade de poder crescer através da redação de textos cientifícos.

$\mathrm{Na}$ verdade, o processo de criação do artigo a ser submetido, exige dos autores uma dedicação diferenciada na criação de protocolos de trabalhos extremamente cuidadosos e que gerem um conhecimento inédito e original permitindo, assim, sua submissão e sucesso em revistas de alto conceito científico. Entretanto, para alcançar esse objetivo três desafios básicos se apresentam.

O primeiro desafio está no uso preferencial da língua inglesa, a qual atualmente tornou-se universal no meio científico. Não estamos nos referindo à língua inglesa no sentido coloquial, mas, numa linguagem literária ora denominada de "inglês acadêmico". Este nível de aperfeiçoamento linguístico é importantíssimo para o sucesso dos artigos publicados e exige uma leitura cuidadosa de outros bons artigos sobre o assunto, como exercício para incremento de seu aprendizado na língua inglesa. Para atingir este objetivo, a principal sugestão é manter criteriosamente e constantemente a leitura de pelo menos três artigos semanais, durante alguns meses. Com esta ação o indivíduo familiariza-se com o vocabulário acadêmico e acaba entendendo o conjunto de estruturas gramaticais comuns a artigos científicos publicados na língua inglesa.

O segundo desafio reside na adoção de protocolos universais obedecendo a critérios estatísticos rigorosos e metodologia altamente difundida na comunidade científica. Desta forma, num bom artigo científico, uma seção de metodologia deve contemplar protocolos perfeitamente validados para aquele objeto de estudo e preferencialmente respaldado por outros grupos científicos que estudaram aquele tema.

O terceiro desafio, e não menos importante, consiste na escolha do periódico para onde se pretende enviar o artigo científico. Uma boa métrica inicial é verificar atentamente se o escopo do periódico contempla o assunto do texto que estamos submetendo. Se assim for, também é pertinente observar se através desse periódico vamos conseguir atingir o público alvo pretendido. Finalmente, para os assuntos especializados, o uso do "fator de impacto" cuja amplitude de seu valor traduz o grau de inserção do periódico na comunidade científica mundial também é uma ferramenta para a tomada de decisão.

Os autores que seguem os critérios ora mencionados para a redação dos seus artigos descobrem por sua vez que o grau de aprendizado é enorme. Muitas vezes já nos deparamos com um "primeiro rascunho" de nosso artigo, que depois de seguidas revisões e opiniões dos pares o "resultado final" é um texto com linguagem adequada, conciso, objetivo e com alto nível de qualidade e que nos traduz uma sensação de orgulho. Geralmente, se os colegas que opinaram em nosso artigo o fizeram de forma correta e sincera, certamente teremos sucesso na submissão do mesmo. Por outro lado, caso nosso artigo seja rejeitado, geralmente as sugestõe $\mathrm{s}$ dos assessores escolhidos, nos levam a novas reflexões e terminamos verificando que as críticas mencionadas são pertinentes e nos induzem a perceber que precisamos evoluir naquele objeto de estudo, apesar de anteriormente acreditarmos que já havíamos atingido um nível de excelência.

Desta forma, a redação de artigos científicos é um caminho de aprendizado constante que permite uma evolução gradual e progressiva em nossa formação profissional. $\mathrm{O}$ processo de criação de artigos científicos transforma-se numa ferramenta primordial para o aperfeiçoamento de grupos de pesquisa e de profissionais envolvidos neste processo.

Por isso isto, cabe aos editores de periódicos científicos a missão de transformar o periódico numa ferramenta de enobrecimento e formação profissional de seus leitores e daqueles que buscam ali publicar. Portanto, a decisão editorial deve ser prioritariamente baseada em critérios técnicos e meritocráticos sempre fundamentada na assessoria dos pares que analisaram o texto. Neste contexto, não existe qualquer influência política na decisão editorial. Só desta forma teremos um períodico respeitado mundialmente e com critérios de qualidade que farão seu uso ser um objeto transformador na vida dos leitores e da comunidade científica geral. É dentro desses princípios que o periódico Infarma-Ciências Farmacêuticas tem fundamentado suas decisões editoriais. 